Materiales de Construcción

Vol. 66, Issue 321, January-March 2016, e075

ISSN-L: 0465-2746

http://dx.doi.org/10.3989/mc.2016.08414

\title{
A proposal for the maximum use of recycled concrete sand in masonry mortar design
}

\author{
E. Fernández-Ledesma ${ }^{\mathrm{a}}$, J.R. Jiménez $^{\mathrm{a}} \bowtie$, J. Ayuso $^{\mathrm{a}}$, V. Corinaldesi ${ }^{\mathrm{b}}$, F.J. Iglesias-Godino ${ }^{\mathrm{c}}$ \\ a. Construction Engineering Area. University of Córdoba (Córdoba, Spain) \\ b. Department of Materials and Environment Engineering and Physics, Università Politecnica delle Marche (Ancona, Italy) \\ c. Department of Chemical, Environmental, and Materials Engineering, University of Jaen (Jaen, Spain) \\ $\triangle$ jrjimenez@uco.es
}

\begin{abstract}
Natural sand mining from rivers and seashores is causing serious environmental problems in many parts of the world, whereas the fine fraction from recycling concrete waste is underutilized as a construction material. The aim of this paper is to determine the maximum replacement level of natural sand by recycled sand in the manufacturing of masonry mortar (M-10). For this purpose, five replacement levels were tested: $0 \%, 25 \%$, $50 \%, 75 \%$ and $100 \%$ by volume. The mixes were made using cement CEM II/BL $32.5 \mathrm{~N}$ in a volumetric proportion of cement-to-aggregate of 1:5. A commercial admixture was used at a constant content. The amount of water was variable to achieve a consistency of $175 \pm 10 \mathrm{~mm}$. The short- and long-term mortar properties were evaluated. The data were analyzed using a one-way ANOVA. In conclusion, a maximum percentage of $50 \%$ recycled concrete sand can be used in an indoor environment.
\end{abstract}

KEYWORDS: Mortar; Compressive Strength; Mechanical Properties; Retraction; Waste Treatment

Citation/Citar como: Fernández-Ledesma, E. Jiménez, J.R.; Ayuso, J.; Corinaldesi, V.; Iglesias-Godino, F.J. (2016) A proposal for the maximum use of recycled concrete sand in masonry mortar design. Mater. Construcc. 66 [321], e075 http://dx.doi.org/10.3989/mc.2016.08414.

RESUMEN: Propuesta de máximo uso de arena reciclada de hormigón en el diseño de morteros de albañilería. La extracción de arena natural de ríos y costas está provocando graves problemas ambientales en muchas partes del mundo, mientras que la fracción fina de los áridos reciclados de residuos de hormigón está infrautilizada como material de construcción. El objetivo de este artículo es determinar el máximo porcentaje de sustitución de arena natural por arena reciclada en la fabricación de morteros M-10. Cinco niveles de sustitución en volumen fueron ensayados: $0 \%, 25 \%, 50 \%, 75 \%$ y 100\%. Las mezclas fueron hechas con cemento CEM II/BL 32,5 $\mathrm{N}$ en una relación volumétrica cemento-árido de 1:5. Se utilizó un aditivo comercial a dosis constante. El agua se ajustó experimentalmente para conseguir una consistencia de $175 \pm 10 \mathrm{~mm}$. Se evaluaron las propiedades de los morteros a corto y largo plazo. Los datos se analizaron mediante una ANOVA-simple. En conclusión, un porcentaje máximo del 50\% de arena reciclada de hormigón puede usarse en interiores.

PALABRAS ClAVE: Mortero; Resistencia a Compresión; Propiedades Mecánicas; Retracción; Tratamiento De Residuos

Copyright: (C) 2016 CSIC. This is an open-access article distributed under the terms of the Creative Commons Attribution-Non Commercial (by-nc) Spain 3.0 License. 


\section{INTRODUCTION}

Concrete is one of the most widely used materials in the world for making architectural structures, foundations, walls, pavements, bridges, dams, reservoirs, pipes and precast elements. Conventional concrete is not considered an environmentally friendly material because of the use of non-renewable natural resources, such as sand and gravel, and its high embodied energy. In most cases, these concrete elements are demolished at the end of their useful life, generating what is known as construction and demolition waste (CDW). Using selective demolition techniques, very pure concrete waste with a high potential for recycling can be obtained (1). For this, all non-mineral dry building materials, such as plasterboards, wood, metals, plastics, should be removed and separated before the demolition of concrete elements. Indeed, in some cases, it may also be worthwhile to separate ceramic elements such as brick and tiles. This has led to the concept of deconstruction techniques (2).

Concrete waste is treated in recycling plants, where the reinforced steel is removed from the concrete rubble. Concrete rubble is crushed in an impact or jaw crusher to reduce the grain size to produce recycled concrete aggregate (RCA). Depending on its subsequent use, the RCA is screened to obtain different sizes. If the RCA is to be used in road pavement, it is screened to obtain $0 / 22 \mathrm{~mm}, 0 / 32 \mathrm{~mm}$ or $0 / 40 \mathrm{~mm}$ fractions $(3,4)$, but for its use in the manufacture of new concrete or mortar, the RCA is screened to obtain two different fractions: a coarse fraction $(4 / 16 \mathrm{~mm}, 4 / 22 \mathrm{~mm}$, or $4 / 32 \mathrm{~mm})$ and a fine fraction $(0 / 4 \mathrm{~mm})$. The manufacture of concrete and mortars allows for greater added value to RCA.

The use of fine RCA (recycled concrete sand) has been investigated less than the coarse fraction in concrete manufacturing because of its inferior properties, such as a larger amount of cement paste, higher water absorption and more sulfur compounds (5). Evangelista and de Brito (6) concluded that replacement ratios of up to $30 \%$ of natural sand by recycled concrete sand does not jeopardize the mechanical properties of concrete. Kou and Poon (7) showed that it is possible to use fine RCA in concrete, although the use of fine RCA decreased the compressive strength and increased the drying shrinkage of the concrete. The use of superplasticizers improves the mechanical properties of concrete with fine RCA (8). However, the water absorption and non-steady-state chloride migration coefficient increase linearly with the replacement ratio of fine natural aggregate by fine RCA, whereas the carbonation resistance is reduced (9). For durability reasons, the use of fine RCA in structural concrete may pose serious difficulties. Several countries, including China, Germany, Hong Kong, Portugal, Spain and the U.K., forbid the use of fine RCA in the manufacturing of concrete (10). In a recent article, Evangelista and de Brito (11) concluded that, considering the particularities of fine RCA in the method used for the mix design and production, it is possible to replace natural sand with fine RCA to make structural concrete.

The use of fine RCA in the manufacture of nonstructural concrete or masonry mortar, to be used in structures or building elements not affected by durability issues (e.g., partition walls in indoor environments), might constitute an alternative way to recycle this fraction as recycled concrete sand. However, scientific and technical studies on the use of fine RCA in the manufacture of mortar are scarce. Corinaldesi and Moriconi (12) and Corinaldesi (13) concluded that replacement levels up to $100 \%$ by weight of natural sand by recycled concrete sand decreases the flexural and compressive strength with respect to the reference mortar, although the masonry assemblages with recycled mortar displayed excellent mechanical behavior. Dapena et al. (14) reported that the compressive strength dropped linearly with the percentage of replacement of natural sand by recycled concrete sand. Vegas et al. (15) proposed that it is possible to replace, by weight, up to $25 \%$ of natural sand with recycled concrete sand without decreasing the mechanical strength, workability and shrinkage in masonry mortar. These authors replaced natural sand with recycled concrete sand by weight. Because of the lower density of the fine RCA, substituting materials by weight produces a larger volume of lower-quality mortar (16).

Martínez et al. (17) replaced by volume $100 \%$ of natural sand with different types of recycled sand and found that most of the natural aggregate mortars achieved higher mechanical properties than the recycled aggregate mortars. Very fine RCA, with particle sizes less than $0.150 \mathrm{~mm}$, have also been used in mortars. Braga et al. (18) obtained very satisfactory results for most of the mortars prepared with different incorporation levels of fine concrete aggregates. Neno et al. (19) studied the effect of different replacement levels of river sand by recycled concrete sand on mortar properties, although these authors did not propose a maximum replacement ratio that meets all the performance requirements of mortars. Ledesma et al. (20) evaluated the short- and long-term properties of masonry mortar and concluded that a replacement ratio of up to $40 \%$ is a viable alternative for masonry mortar production. Cuenca-Moyano et al. (21) studied the influence of pre-soaked recycled fine aggregates from $\mathrm{CDW}$ on the properties of masonry concrete and concluded that this method may be more effective to compensate for the higher water absorption of recycled aggregates.

The aim of this work was to establish the maximum feasible replacement level of natural sand by recycled concrete sand in the manufacturing of masonry mortars. For this study, the performances 
of fresh and hardened mortar with replacement levels of up to $100 \%$ by volume were tested. The findings of this article support the use of recycled concrete sand, as it minimizes the consumption of non-renewable natural resources such as natural sand from rivers, reduces the energy consumption and $\mathrm{CO}_{2}$ emissions that occur when rock and gravel are crushed to produce natural sand and promotes the recycling of construction and demolition waste.

\section{MATERIALS AND EXPERIMENTAL PROCEDURE}

\subsection{Material characterization}

Two different aggregates were used in this study: natural siliceous river sand (NA) as a reference and fine RCA from a recycling plant located in northern Córdoba, Spain. The recycling plant was equipped with a mobile crushing unit with a magnetic ferrous metal separator and a mobile vibrating screen with two sieves that could produce three recycled aggregate fractions: $0 / 8 \mathrm{~mm}, 8 / 40 \mathrm{~mm}$ and $>40 \mathrm{~mm}$. The fine RCA was collected from the $0 / 8 \mathrm{~mm}$ stockpile, and this sample was sieved in the laboratory to remove particles larger than $4 \mathrm{~mm}$ to obtain the same maximum particle size as the NA. The primary constituent of the RCA, determined in accordance with standard UNE-EN 933-11:2009, was concrete (98\%). Only a few impurities, such as asphalt (1.7\%) and ceramics $(0.4 \%)$, were found. Thus, the recycled aggregate used can be considered very pure.

Both sands met the specifications of standard UNE-EN 13139:2002 for mortar aggregates. Table 1 shows the size distribution determined in accordance with European standard UNE-EN 933-1:2006 and Table 2 shows the materials' physico-mechanical and chemical properties. The fine RCA had approximately double the fine content $(<0.063 \mathrm{~mm})$, similar sand equivalents, a higher water absorption, lower dry density and higher friability coefficient than the NA. In the chemical characterization, the fine RCA

TABLE 1. Particle size distribution of materials and uniformity coefficient $(\mathrm{Cu})$

\begin{tabular}{lcc}
\hline & \multicolumn{2}{c}{ Percent passing (\%) } \\
\cline { 2 - 3 } Sieve size (mm) & NA & RCA \\
\hline 4 & 100.00 & 100.00 \\
2 & 87.00 & 74.00 \\
1 & 73.00 & 43.00 \\
0.5 & 53.00 & 25.00 \\
0.25 & 23.00 & 14.00 \\
0.125 & 8.00 & 9.00 \\
0.063 & 3.20 & 6.00 \\
$\mathrm{Cu}$ & 5.0 & 11.0 \\
\hline
\end{tabular}

did not exceed the $1 \%$ sulfur and soluble salt ceilings set by standard UNE-EN 13139:2002 for total sulfur compounds $(1 \%)$. Organic matter or other substances that might have altered the mortar setting time were not detected. The water-soluble chlorides and the loss on ignition were higher than for the NA. Both materials were classified as non-reactive according to UNE 146507-1:1999. All results were in agreement with the properties described in the literature for RA from CDW $(17,22)$.

The aggregates were also analyzed by powder X-ray diffraction patterns (PXRD) using a Siemens $\mathrm{D}-5000$ instrument with $\mathrm{CuK} \alpha$ radiation. The equipment used is as described by Jiménez et al. (16); the main crystalline phase was quartz for both the NA and RCA (Table 3), whereas the other minor phases were calcite, dolomite, illite, albite and sanidine. These results depend on the mineralogical composition of the virgin aggregates used in the manufacture of concrete and reflect the geological environs of the plant location (23).

The environmental performance of the fine aggregates was assessed using the UNE-EN 12457-3:2003 leaching test. This standard is a two-step batch leaching test in which $175 \mathrm{~g}$ of dry samples of material at liquid to solid ratios (L/S) of 2 and $101 / \mathrm{kg}$ are used. The quantities of several major and trace elements were determined in the laboratory using inductively coupled plasma mass spectrometry (ICP-MS). Table 4 shows the leached concentrations $(\mathrm{mg} / \mathrm{kg})$ for $\mathrm{L} / \mathrm{S}=2$ and $\mathrm{L} / \mathrm{S}=10$ and the limits established in Annex 2 of the 2003/33/CE Council Decision for landfill classification. Both materials were classified as inert. As shown in this table, the amount of $\mathrm{Cr}$ and $\mathrm{SO}_{4}^{-}$leachate was higher in the fine $\mathrm{RCA}$ than NA. These elements come from the cement composition and in some cases exceed the limit of inert materials (16).

A cement type CEM-II/BL $32.5 \mathrm{~N}$, according to UNE-EN 197-1:2011, was used to make the mortar. A commercial admixture (NEOPLAST) was mixed directly into the water at a dosage of $0.1 \mathrm{~cm}^{3}$. This admixture is a conventional plasticizer for mortars used to improve the workability and reduce the amount of mixing water. Pereira et al. (8) and Cartuxo et al. (24) demonstrated that the use of admixtures in concrete made with fine RCA exhibited better mechanical and rheological performance than the reference mixes without admixtures.

\subsection{Mortar batching}

To design the mortar mixture proportions, the following criteria were established.

a) Maintaining the original grading curves below $4 \mathrm{~mm}$ for NA and fine RCA.

b) Maintaining a volumetric proportion of cementto-aggregate of $1: 5$ in all mixes. 
TABLE 2. Characterization of aggregate for mortars

\begin{tabular}{llccc}
\hline Characteristic & Standard & AN & RCA & $\begin{array}{c}\text { Limit set by } \\
\text { UNE-EN 13139 }\end{array}$ \\
\hline Fine content $(\%)^{(\mathrm{a})}$ & UNE-EN 933-1 & 3.2 & 6.1 & $\leq 8$ \\
Sand equivalent $(\%)$ & UNE-EN 933-8 & 83 & 88 & No limit \\
Dry sample density ${ }^{(\mathrm{b})} \rho_{\text {rd }}\left(\mathrm{g} / \mathrm{cm}^{3}\right)$ & UNE-EN 1097-6 & 2.63 & 2.2 & No limit \\
Water absorption $^{(\mathrm{b})}(\%)$ & UNE-EN 1097-6 & 0.79 & 8.26 & No limit \\
Friability coefficient $(\%)$ & UNE 83115 & 15 & 23 & No limit \\
Acid soluble sulfates $\left(\% \mathrm{SO}_{3}\right)$ & UNE-EN 1744-1 & $<0.01$ & 0.40 & $\leq 0.8$ \\
Total sulfurs $\left(\% \mathrm{SO}_{3}\right)$ & UNE-EN 1744-1 & $<0.01$ & 0.40 & $\leq 1$ \\
Humic content $(\%)$ & UNE-EN 1744-1 & $\mathrm{ND}^{(\mathrm{c})}$ & $\mathrm{ND}^{(\mathrm{c})}$ & No limit \\
Fulvic acid $(\%)$ & UNE-EN 1744-1 & $\mathrm{ND}^{(\mathrm{c})}$ & $\mathrm{ND}^{(\mathrm{c})}$ & No limit \\
Water soluble chlorides $(\% \mathrm{Cl})$ & UNE-EN 1744-1 & $<0.01$ & 0.07 & $\leq 0.15$ \\
Loss of ignition $(\%)$ & UNE-EN 1744-1 & 6.56 & 11.12 & No limit \\
Soluble salts 1:2 (\%) & Gravimetric & 0.128 & 0.545 & $\leq 1$ \\
\hline
\end{tabular}

(a) Finer than $0.063 \mathrm{~mm}$.

(b) Fraction $0.063 / 4 \mathrm{~mm}$.

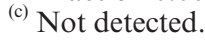

c) A gradual increase in the incorporation of fine RCA: $0 \%, 25 \%, 50 \%, 75 \%$ and $100 \%$. Five mortars were tested: MA-100/0, MF-75/25, MG-50/50, MH-25/75 and MI-0/100.

d) A replacement by volume of the NA by RCA. The dry mass of each component was calculated using the formulas [1] to [4].

$$
\text { Dry mass of cement }=\frac{\mathrm{V} \cdot 1 \cdot \operatorname{\rho rdCEM}}{6}
$$

Dry mass of $\mathrm{RCA}=\frac{\mathrm{V} \cdot \mathrm{X} \cdot 5 \cdot \rho \mathrm{rdRCA}}{6}$

$$
\text { Dry mass of } \mathrm{NA}=\frac{\mathrm{V} \cdot(1-\mathrm{X}) \cdot 5 \cdot \rho \mathrm{rNA}}{6}
$$

$X=\frac{\text { Percentage of replacement of NA by RCA }}{100}$

TABLE 3. Mineralogical analysis of NA and fine RCA

\begin{tabular}{lcc}
\hline & \multicolumn{2}{c}{ Mineral relative abundance $\left(^{*}\right)$} \\
\cline { 2 - 3 } Mineral phase & NA & RCA \\
\hline Albite $\mathrm{Na}\left(\mathrm{Si}_{3} \mathrm{Al}\right) \mathrm{O}_{8}$ & $*$ & $* *$ \\
Calcite $\mathrm{CaCO}_{3}$ & $* *$ & $* *$ \\
Dolomite $\left.\mathrm{CaMg}_{2} \mathrm{CO}_{3}\right)_{2}$ & $* *$ & \\
Illite $\mathrm{KAl}_{2} \mathrm{Si}_{3} \mathrm{AlO}_{20}(\mathrm{OH})_{2}$ & $*$ & $*$ \\
Quartz $\left(\mathrm{SiO}_{2}\right)$ & $* * * * *$ & $* * * *$ \\
Sanidine $(\mathrm{Na}, \mathrm{K})\left(\mathrm{Si}_{3} \mathrm{Al}_{1}\right) \mathrm{O}_{8}$ & $* *$ & $*$ \\
\hline
\end{tabular}

Table 5 shows the dry mass of $1600 \mathrm{~cm}^{3}$ of components. Due to RCA's lower density, the dry mass of RCA was lower than that of NA for the same volume of mixed material.

e) No pre-saturation of the fine RCA. Based on the study of Ferreira et al. (25), the aggregates were not previously pre-saturated. RCA were used with their natural moisture $(2.7 \%)$.

f) Use of a fixed amount of admixture in all mixes. The admixture was added directly into the water at a dosage of $0.1 \mathrm{~cm}^{3}$.

g) The water content was set experimentally to achieve a consistency of $175 \pm 10 \mathrm{~mm}$ (UNE-EN 1015-3:1999). As the replacement ratio increased, it was necessary to increase the amount of water because of the higher water absorption of fine RCA. The total water/cement ratio (w/c) ranged from 0.78 in the MA-100/0 to 0.97 in the MI-0/100 mortar, whereas the effective w/c ratio obtained by subtracting the difference in water absorbed by the NA and RCA over $24 \mathrm{~h}$ ranged from 0.75 in MA-100/0 to 0.65 in MI-0/100. The decrease in the $(\mathrm{w} / \mathrm{c})_{\mathrm{ef}}$ ratio with the incorporation of the fine RCA is explained by the recycled aggregates not absorbing their potential capacity $(24 \mathrm{~h})$ during the mixing period (3, $4 \mathrm{~min})$. Pereira et al. $(8,26)$ showed the fine RCA's water absorption over time and found that after $10 \mathrm{~min}$ the fine RCA had absorbed $50 \%$ of its potential capacity.

\subsection{Mixing procedure}

The mortars were mixed in a standard mixer (UNE-EN 196-1:1996) according to the procedure described by Jiménez et al. (16). 
A proposal for the maximum use of recycled concrete sand in masonry mortar design $\bullet 5$

TABLE 4. Leached concentrations of NA and fine RCA (mg/kg) and waste acceptance criteria (EU Council Decision 2003/33/EC)

\begin{tabular}{|c|c|c|c|c|c|c|c|c|c|c|}
\hline \multirow[b]{3}{*}{ Element } & \multirow{2}{*}{\multicolumn{2}{|c|}{ NA }} & \multirow{2}{*}{\multicolumn{2}{|c|}{ RCA }} & \multicolumn{6}{|c|}{ Criteria EU Landifill Directive 2003/33/EC } \\
\hline & & & & & \multicolumn{2}{|c|}{ Inert } & \multicolumn{2}{|c|}{ Non-hazardous } & \multicolumn{2}{|c|}{ Hazardous } \\
\hline & $\mathrm{L} / \mathrm{S}=\mathbf{2}$ & $\mathrm{L} / \mathrm{S}=10$ & $\mathrm{~L} / \mathrm{S}=\mathbf{2}$ & $L / S=10$ & $\mathrm{~L} / \mathrm{S}=\mathbf{2}$ & $\mathrm{L} / \mathrm{S}=10$ & $L / S=2$ & $\mathrm{~L} / \mathrm{S}=10$ & $\mathrm{~L} / \mathrm{S}=\mathbf{2}$ & $\mathrm{L} / \mathrm{S}=\mathbf{1 0}$ \\
\hline $\mathrm{Cr}$ (Chromium) & 0.001 & 0.000 & 0.172 & 0.338 & 0.2 & 0.5 & 4 & 10 & 25 & 70 \\
\hline Ni (Nickel) & 0.000 & 0.000 & 0.004 & 0.003 & 0.2 & 0.4 & 5 & 10 & 20 & 40 \\
\hline $\mathrm{Cu}$ (Copper) & 0.000 & 0.003 & 0.052 & 0.074 & 0.9 & 2 & 25 & 50 & 50 & 100 \\
\hline Zn (Zinc) & 0.001 & 0.002 & 0.001 & 0.002 & 2 & 4 & 25 & 50 & 90 & 200 \\
\hline As (Arsenic) & 0.013 & 0.061 & 0.003 & 0.017 & 0.1 & 0.5 & 0.4 & 2 & 6 & 25 \\
\hline Se (Selenium) & 0.003 & 0.013 & 0.007 & 0.005 & 0.06 & 0.1 & 0.3 & 0.5 & 4 & 7 \\
\hline Mo (Molybdebum) & 0.001 & 0.000 & 0.096 & 0.180 & 0.3 & 0.5 & 5 & 10 & 20 & 30 \\
\hline Cd (Cadmium) & 0.000 & 0.000 & 0.000 & 0.000 & 0.03 & 0.04 & 0.6 & 1 & 3 & 5 \\
\hline Sb (Antimony) & 0.001 & 0.002 & 0.001 & 0.019 & 0.02 & 0.06 & 0.2 & 0.7 & 2 & 5 \\
\hline $\mathrm{Ba}$ (Barium) & 0.025 & 0.091 & 0.195 & 1.340 & 7 & 20 & 30 & 100 & 100 & 300 \\
\hline Hg (Mercury) & 0.000 & 0.000 & 0.000 & 0.000 & 0.003 & 0.01 & 0.05 & 0.2 & 0.5 & 2 \\
\hline $\mathrm{Pb}$ (Plumb) & 0.000 & 0.000 & 0.000 & 0.000 & 0.2 & 0.5 & 5 & 10 & 25 & 50 \\
\hline Fluoride & $<2$ & $<10$ & $<2$ & $<10$ & 4 & 10 & 60 & 150 & 200 & 500 \\
\hline Chloride & 14.2 & $<50$ & 51.932 & 69.74 & 550 & 800 & 10000 & 15000 & 17000 & 25000 \\
\hline Sulphate & 34.5 & $<50$ & 318 & 840 & 560 & 1000 & 10000 & 20000 & 25000 & 50000 \\
\hline \multicolumn{11}{|c|}{ Conditions of the test sample } \\
\hline Conductivity $(\mu \mathrm{S} / \mathrm{cm})$ & 56.5 & 32.5 & 995 & 641 & & & & & & \\
\hline Temperature $\left({ }^{\circ} \mathrm{C}\right)$ & 27.9 & 25.5 & 27.9 & 25.8 & & & & & & \\
\hline $\mathrm{pH}$ & 8.88 & 9.38 & 11.6 & 11.44 & & & & & & \\
\hline
\end{tabular}

TABLE 5. Mortar mixture proportions

\begin{tabular}{lccccccccc}
\hline & & \multicolumn{7}{c}{ Mix proportions - dry weight } \\
\cline { 3 - 9 } Mortar type & NA/RCA & NA $(\mathbf{g})$ & RCA $(\mathbf{g})$ & CEM $(\mathbf{g})$ & Water $(\mathbf{g})$ & $\begin{array}{c}\text { Admixture } \\
\left(\mathbf{c m}^{3}\right)\end{array}$ & $\begin{array}{c}\text { Consistency } \\
(\mathbf{m m})\end{array}$ & w/c & $(\mathbf{w} / \mathbf{c})_{\text {ef }}$ \\
\hline MA & $100 / 0$ & 3.508 & 0 & 757 & 596 & 0.1 & 181 & 0.78 & 0.75 \\
MF & $75 / 25$ & 2.631 & 734 & 757 & 629 & 0.1 & 174 & 0.83 & 0.72 \\
MG & $50 / 50$ & 1.754 & 1.467 & 757 & 667 & 0.1 & 178 & 0.87 & 0.69 \\
MH & $25 / 75$ & 877 & 2.201 & 757 & 701 & 0.1 & 175 & 0.92 & 0.67 \\
MI & $0 / 100$ & 0 & 2.935 & 757 & 754 & 0.1 & 172 & 0.97 & 0.65 \\
\hline
\end{tabular}

$\mathrm{NA} / \mathrm{RCA}=$ percentage in volume of natural aggregates/percentage of recycled concrete aggregate.

\subsection{Tests}

Three properties were tested to evaluate the fresh mortar: density, air content and workability. The hardened mortar was characterized by studying seven properties: dry bulk density, flexural strength, compressive strength, dimensional instability (shrinkage), adhesive strength, water absorption due to capillary action and durability. Four different mixes of each mortar type were made. Table 6 shows the testing standards used and the climatic conditions of the three climatic chambers used in these tests. The test methods are described in their correspondent standard, except for the durability test.

According to Vegas et al. (15), the durability test was focused on determining resistance to salt crystallization (UNE-EN 12370:1999). This test method, described in the standard for natural stone, was applied to $40 \times 40 \times 160-\mathrm{mm}$ prismatic specimens. After drying to constant mass, the specimens were immersed in a sodium sulfate solution and then dried in an oven and left to cool to laboratory temperature. This cycle was repeated 15 times, and the percentage change in mass was determined. 
TABLE 6. Standard used to characterise the mortar properties

\begin{tabular}{|c|c|c|c|c|}
\hline Properties of fresh mortar & Standard & Specimens and dimensions & Climatic chamber & Curing time \\
\hline $\begin{array}{l}\text { Bulk density of the fresh } \\
\text { mortar }\end{array}$ & UNE-EN 1015-6:1998 & 4 & Chamber-2 & \\
\hline Entrained air & UNE-EN 1015-7:1998 & 4 & Chamber-2 & \\
\hline Workability & UNE-EN 1015-9:2000 & 4 & Chamber-2 & \\
\hline \multicolumn{5}{|l|}{ Properties of hardened mortar } \\
\hline Dry bulk density & UNE-EN 1015-10:1999 & 4 Prismatic $40 \times 40 \times 160 \mathrm{~mm}$ & $\begin{array}{l}\text { Chamber-1 ( } 7 \text { days) Chamber- } 2 \\
\text { (rest of curing time) }\end{array}$ & 28 days \\
\hline Flexural strength & UNE-EN 1015-11:1999 & 4 Prismatic $40 \times 40 \times 160 \mathrm{~mm}$ & $\begin{array}{l}\text { Chamber- } 1 \text { ( } 7 \text { days) Chamber- } 2 \\
\text { (rest of curing time) }\end{array}$ & $7,28,90,180$ days \\
\hline Compressive strength & UNE-EN 1015-11:1999 & 8 Prismatic $40 \times 40 \times 80 \mathrm{~mm}$ & $\begin{array}{l}\text { Chamber- } 1 \text { ( } 7 \text { days) Chamber- } 2 \\
\text { (rest of curing time) }\end{array}$ & $7,28,90,180$ days \\
\hline Shrinkage & UNE-83831 EX:2010 & 3 Prismatic $40 \times 40 \times 160 \mathrm{~mm}$ & $\begin{array}{l}\text { Chamber- } 1 \text { ( } 7 \text { days) Chamber- } 2 \\
\text { (rest of curing time) }\end{array}$ & Up to 203 days \\
\hline Adhesive strength & UNE-EN 1015-12:2000 & $\begin{array}{l}4 \text { Circular-50 mm } \\
\text { diameter, } 10 \mathrm{~mm} \text {-thick }\end{array}$ & $\begin{array}{l}\text { Chamber-1 ( } 7 \text { days) Chamber- } 2 \\
\text { (rest of curing time) }\end{array}$ & 28 days \\
\hline $\begin{array}{l}\text { Water absorption due to } \\
\text { capillary }\end{array}$ & UNE-EN 1015-18:2002 & 6 Prismatic $40 \times 40 \times 80 \mathrm{~mm}$ & $\begin{array}{l}\text { Chamber-1 ( } 7 \text { days) Chamber- } 2 \\
\text { (rest of curing time) }\end{array}$ & 28 days \\
\hline Durability & UNE-EN 12370:1999 & 4 Prismatic $40 \times 40 \times 160 \mathrm{~mm}$ & - & 180 days \\
\hline
\end{tabular}

${ }^{(1)}$ Climatic conditions: Chamber $-1: \mathrm{T}^{\mathrm{a}}=20 \pm 2{ }^{\circ} \mathrm{C} \mathrm{HR}=95 \pm 5 \%$; Chamber $-2: \mathrm{T}^{\mathrm{a}}=20 \pm 2{ }^{\circ} \mathrm{C} \mathrm{HR}=65 \pm 5 \%$.

\subsection{Statistical analysis}

To determine whether the replacement ratio had a statistically significant effect on the mortar's properties, a one-way ANOVA was conducted. If the $\mathrm{p}$-value of the F-test is greater than 0.05 , there is no statistically significant difference between the mean values from one level of replacement to another at the $95.0 \%$ confidence level. If the p-value of the F-test is less than 0.05 , there is a significant difference between the mean values from one level of replacement to another at the $95.0 \%$ confidence level. A multiple range test was also conducted to determine which means were significantly different from the others. Homogeneous groups were identified using columns of Xs. For replacement ratios whose mean values had statistically significant differences, a trend line was adjusted with the aim of studying the effect of the incorporation of fine RCA on the 'measured property'.

\section{RESULTS AND DISCUSSION}

\subsection{Bulk density of fresh mortar}

The p-value of the F-test was less than 0.05 ( $p$-value $=0.000$ ); thus, the bulk density of fresh mortar was affected by the incorporation of fine RCA. From a statistical standpoint, three homogeneous groups were identified in the multiple range tests. Table 7 shows that there were no statistically significant differences between the mean values of mixes with replacement ratios below 50\%. Analyzing the evolution of these mean values (Figure 1), the fresh bulk density slightly increased with a replacement ratio of $25 \%$ and decreased linearly with higher replacement levels.

These results can be explained three different ways. The higher amount of very fine particles $(<0.063 \mathrm{~mm})$ of RCA that at low rates of replacement has a filler effect on the matrix of mortar consequently produces a higher density. The higher uniformity coefficient of RCA gives greater compactness to the mix $(27,28)$. The lower particle density of RCA, at replacement rates above $25 \%$, has a greater effect than the previous two.

Neno et al. (19) showed that fresh bulk density decreased linearly as the content of RCA increased. These authors did not observe a higher fresh bulk density in mixes with low replacement rates of NA by fine RCA. This can be explained because these

TABLE 7. Multiple Range Test for the bulk density of fresh mortar. Method: $95 \%$ LSD

\begin{tabular}{lcccc}
\hline Mortar & Count & $\begin{array}{c}\text { LS mean } \\
\left(\mathbf{k g / m ^ { 3 } )}\right.\end{array}$ & $\begin{array}{c}\text { SD } \\
\left(\mathbf{k g / \mathbf { m } ^ { 3 } )}\right.\end{array}$ & $\begin{array}{c}\text { Homogeneous } \\
\text { groups }\end{array}$ \\
\hline MA-100/0 & 4 & 1950 & 23 & $\mathrm{X}$ \\
MF-75/25 & 4 & 1963 & 25 & $\mathrm{X}$ \\
MG-50/50 & 4 & 1943 & 17 & $\mathrm{X}$ \\
MH-25/75 & 4 & 1910 & 8 & \multicolumn{2}{|c}{} \\
MI-0/100 & 4 & 1867 & 22 & X \\
\hline
\end{tabular}




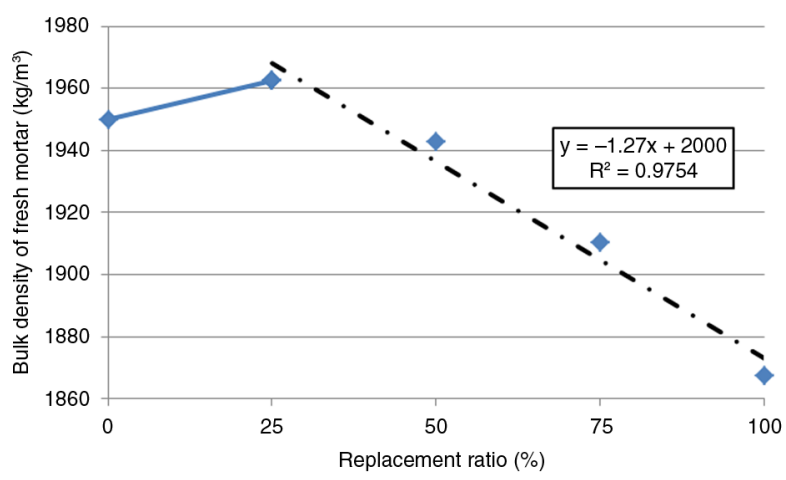

FIGURE 1. Bulk density of fresh mortar vs. replacement ratio.

authors kept the particle size distribution constant in all mixes. The maximum loss observed by Neno et al. (19) was 6.8\%, whereas in this study the maximum loss was $4.2 \%$. The use of fine RCA caused less of a decrease than the fine ceramic aggregates. Jiménez et al. (16) demonstrated that the use of fine RA from ceramic waste caused significant differences from the reference mortar, with replacement rates above $5 \%$.

This is not a limiting property because the European standards do not set a minimum or maximum value for masonry mortar. A maximum replacement ratio of $100 \%$ could be suggested for masonry mortar production to ensure proper performance in terms of the bulk density of fresh mortar.

\subsection{Entrained air content}

The p-value of the F-test was greater than 0.05 (p-value $=0.061)$; thus, the replacement ratio did not have a significant effect on this property. Due to the high dispersion of the data, the multiplerange test showed only one homogeneous group (Table 8). The replacement ratio of $25 \%$ that showed the highest fresh bulk density also showed the lowest entrained air content, which is a consistent result. From a statistical standpoint, this is not a limiting property and a maximum replacement ratio of $100 \%$ can be proposed for masonry

TABLE 8. Multiple Range Test for entrained air content. Method: 95\% LSD

\begin{tabular}{lcccc}
\hline Mortar & Count & $\begin{array}{c}\text { LS mean } \\
(\%)\end{array}$ & SD (\%) & $\begin{array}{c}\text { Homogeneous } \\
\text { groups }\end{array}$ \\
\hline MA-100/0 & 4 & 10.8 & 0.7 & $\mathrm{X}$ \\
MF-75/25 & 4 & 8.5 & 1.3 & $\mathrm{X}$ \\
MG-50/50 & 4 & 9.8 & 1.3 & $\mathrm{X}$ \\
MH-25/75 & 4 & 9.0 & 3.1 & $\mathrm{X}$ \\
MI-0/100 & 4 & 8.5 & 0.9 & $\mathrm{X}$ \\
\hline
\end{tabular}

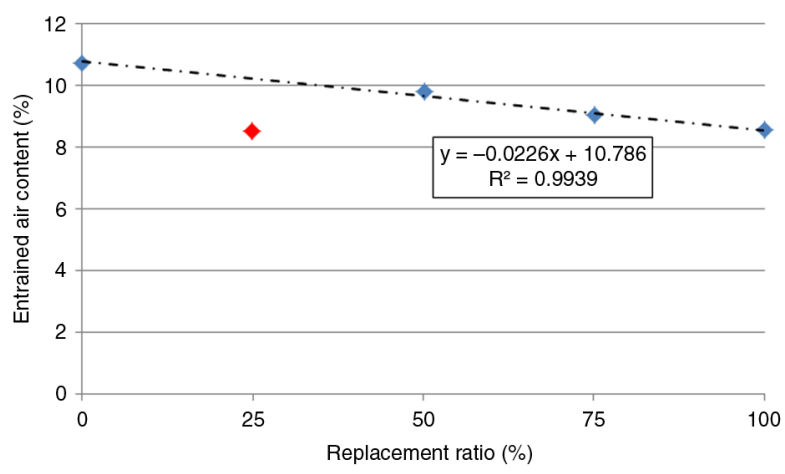

FIGURE 2. Entrained air content vs. replacement ratio.

mortar production to ensure proper performance in terms of entrained air content. Although the statistical results, the entrained air content mean values, decreased linearly as the fine RCA content increased (Figure 2).

Ledesma et al. (20) and Vegas et al. (15) found no significant differences in the entrained air values of mortars with a $25 \%$ and $40 \%$ replacement of natural sand by fine RCA, respectively. Cuenca-Moyano et al. (21) found that the use of pre-soaked recycled fine aggregate reduced the air content slightly. These authors also observed a clear influence of the w/c ratio on the air content of masonry mortar: the air content increased with the total w/c ratio. In contrast, the air content decreased with bulk and dry bulk density. Most researchers have not included this test in their work.

\subsection{Workability}

The p-value of the F-test was less than 0.05 ( $p$-value $=0.000)$; thus, the 'replacement ratio' factor had a significant effect on this property. Four homogeneous groups were identified in the multiple range tests. Table 9 shows that there were no statistically significant differences between the mean values of mixes with replacement ratios below $25 \%$. Figure 3 shows that the mean workability values decreased

TABLE 9. Multiple Range Test for workability. Method: $95.0 \%$ LSD

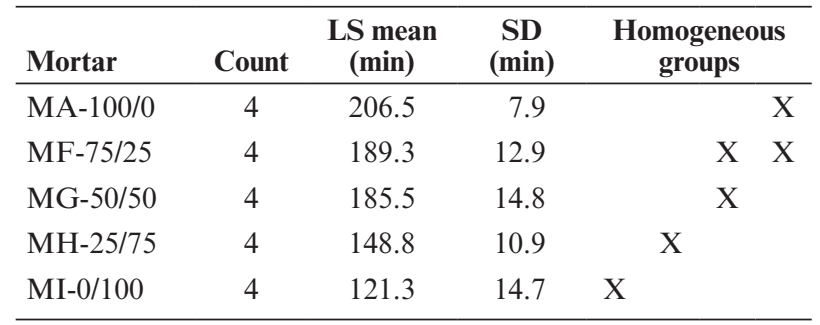




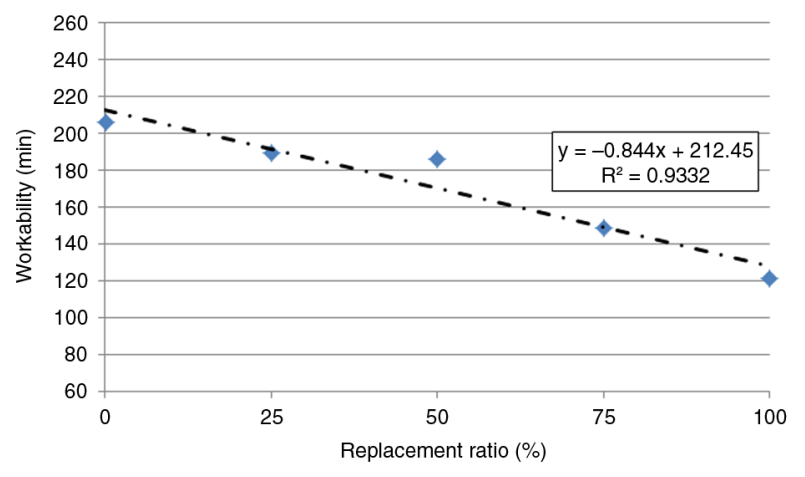

FIGURE 3. Workability vs. replacement ratio.

linearly as the content of fine RCA increased. This phenomenon occurs because RCA's absorption capacity of water was higher than that of NA, and the amount of water required to saturate the aggregates was not added during the mixing process. Figure 4 shows how the effective water/cement ratio decreased linearly as the replacement ratio increased.

Workability is a key aspect for the mason to be able to produce quality masonry work. However, few authors have studied the effect of the incorporation of fine RCA on this property. Ledesma et al. (20) found a maximum loss on the workability of $57.5 \%$, using a replacement ratio of fine RCA of $40 \%$. In a previous work, Jiménez et al. (16) found a maximum loss of 55\% with the same replacement ratio, but in this case using ceramic masonry aggregates. The maximum loss found in this study was $41.3 \%$ with a replacement ratio of $100 \%$. The best results of this study are related to the best control of the environmental conditions in chamber-2 (Table 6), under which the test was performed. Other authors studied water retentivity (prEN 1015-8:1998), a property related to workability. Vegas et al. (15) showed that replacement ratios below $25 \%$ of natural sand by fine RCA did not affect the water retentivity of fresh mortar, and Martínez et al. (17) found minimum differences in

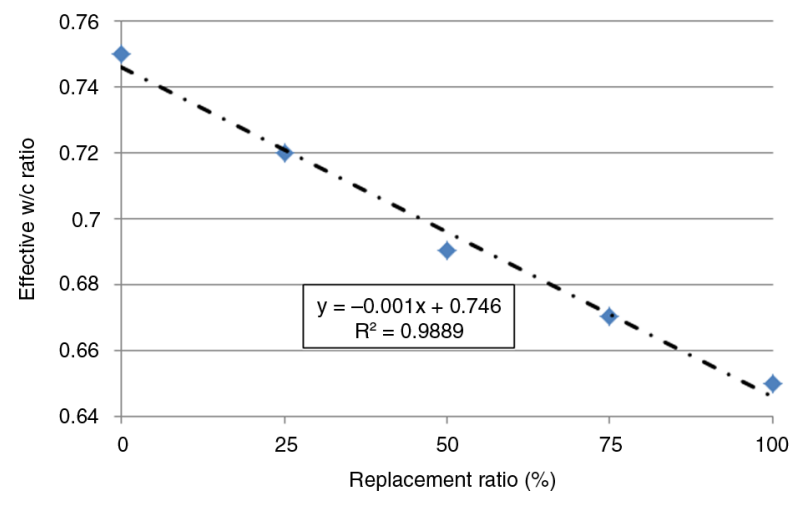

Figure 4. Effective w/c ratio vs. replacement ratio. mortars manufactured with a total replacement level of low-quality natural sand with different types of recycled aggregates from CDW.

One alternative to improve the workability of fresh mortar is pre-saturating the fine $\operatorname{RCA}(29,30)$. The authors believe that pre-saturating the fine RCA is not a viable alternative because fine RCA retain considerable water on their surfaces and pores when wet, increasing the effective water/cement ratio. CuencaMoyano et al. (21) proposed pre-soaking the fine recycled aggregates, but these authors did not study this property. Moreover, there is neither a good technique nor proper facilities to manipulate the wet fine RCA for use in mortar production. If fine RCA is used with its natural moisture, the use of chemical admixtures can be used to improve the workability. Pereira et al. (26) demonstrated that the efficiency of superplasticizers in terms of workability falls as the fine RCA incorporation ratio increases in concrete manufacturing.

From a statistical standpoint, a maximum replacement ratio of $25 \%$ can be proposed for masonry mortar production to ensure proper performance in terms of workability.

\subsection{Dry bulk density of 28-day hardened mortar}

The p-value of the F-test was less than 0.05 ( $p$-value $=0.000$ ); thus, the 'replacement ratio' factor had a significant effect on this property. Four homogeneous groups were identified in the multiple range tests. Table 10 shows that there were no statistically significant differences between the mean values of mixes with replacement ratios below $25 \%$. Figure 5 shows that the mean dry bulk density values again decreased linearly after the $25 \%$ replacement ratio. The reason for the decrease in the dry bulk density is the same as that for the decrease of the fresh bulk density.

These results are consistent with those reported in the literature. Dapena et al. (14) and Vegas et al. (15) found no significant differences with replacement ratios below 20\% and 25\%, respectively. Martínez et al. (17) found lower densities in mortars manufactured with RA from CDW. Neno et al. (19) showed a similar trend, although in that case the authors found

TABLE 10. Multiple range test for dry bulk density of hardened by mortar type. Method: $95 \%$ LSD

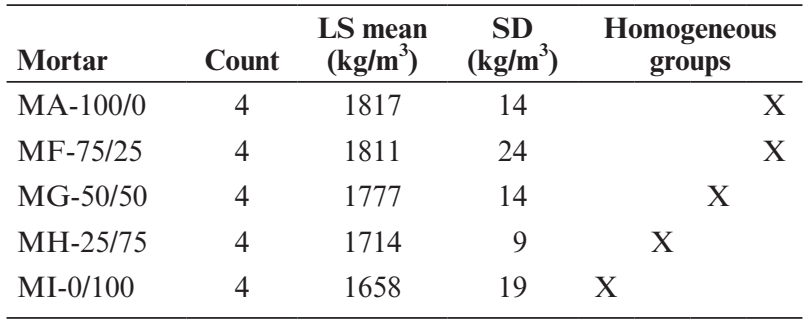




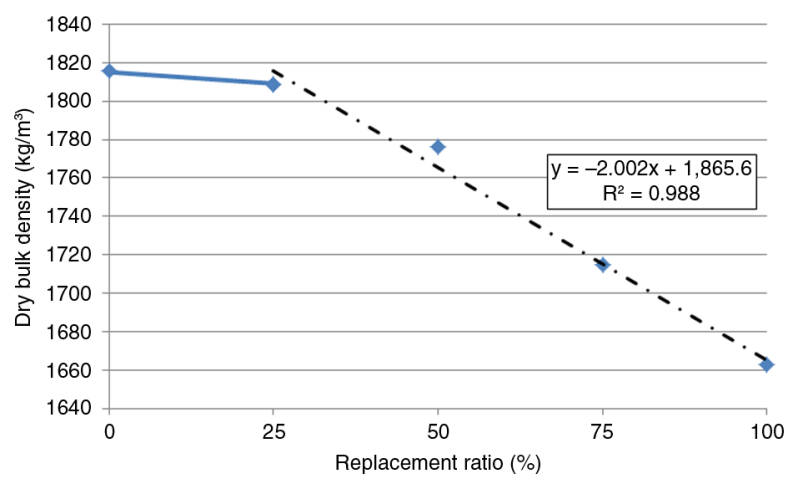

FIGURE 5. Dry bulk density vs. replacement ratio.

a small increase with a $20 \%$ replacement ratio. The maximum losses observed by Neno et al. (19) and in this study were similar $(9.0 \%$ vs. $8.7 \%)$. Ledesma et al. (20) found slight increases with replacement ratios of up to $10 \%$ and decreases with replacement ratios of up to $20 \%$.

For the same reason given for the fresh bulk density, a maximum replacement ratio of $100 \%$ can be proposed for masonry mortar production.

\subsection{Compressive strength of hardened mortar}

From a statistical standpoint, a one-way ANOVA test was conducted at 7, 28, 90 and 180 days of curing. In all cases, the $\mathrm{p}$-value of the F-test was less than 0.05 ( $\mathrm{p}$-value $=0.000)$; thus, the 'replacement ratio' factor had a significant effect on the compressive strength. Table 11 shows the homogeneous groups identified in the multiple-range test. As shown, at early ages more homogeneous groups were identified than at older ages. For all curing times there were no statistically significant differences between the compressive strength mean values in mixes with replacement ratios below 50\%. At 180 days, replacement ratios up to $75 \%$ did not show statistically significant differences with respect to the reference mortar.

The five mortars displayed a similar pattern in compressive strength. The compressive strength for mortars with replacement ratios up to $50 \%$ exceeds the value of $10 \mathrm{MPa}$ required for mortar type M-10 (UNE-EN 998-2:2012) at 28 days of age, whereas the mortars with replacement ratios above $50 \%$ did not reach this value. The mortar with fine RCA showed a greater increase in compressive strength mean values over time. For example, a 10.7\% increase in compressive strength was recorded between the 7- and 180-day reference mortar (MA-100/0), whereas the rise recorded for mortar MG-50/50 was $24.3 \%$ and for mortar MI- $0 / 100$ the rise was $20.2 \%$. This demonstrates that the effect of the fine RCA incorporation is greater at early ages than later ages, which is consistent with the statically homogeneous groups identified in Table 11. In relative terms, the 180-day
TABLE 11. Multiple Range Test for compressive strength of hardened mortar by mortar type and curing time. Method: $95 \%$ LSD

\begin{tabular}{|c|c|c|c|c|c|c|}
\hline Mortar & Count & $\begin{array}{c}\text { LS mean } \\
(\mathrm{MPa})\end{array}$ & $\begin{array}{c}\text { SD } \\
(\mathrm{MPa})\end{array}$ & \multicolumn{3}{|c|}{$\begin{array}{c}\text { Homogeneous } \\
\text { groups }\end{array}$} \\
\hline \multicolumn{7}{|c|}{7 Days (p-value $=0.0004$ ) } \\
\hline MA-100/0 & 4 & 11.2 & 0.4 & & & $X$ \\
\hline MF-75/25 & 4 & 10.9 & 0.8 & & & $\mathrm{X}$ \\
\hline MG-50/50 & 4 & 10.3 & 0.3 & & $\mathrm{X}$ & $\mathrm{X}$ \\
\hline MH-25/75 & 4 & 9.6 & 0.3 & $\mathrm{X}$ & $\mathrm{X}$ & \\
\hline MI-0/100 & 4 & 8.9 & 0.8 & $\mathrm{X}$ & & \\
\hline \multicolumn{7}{|c|}{28 Days $(p-$ value $=0.0000)$} \\
\hline MA-100/0 & 4 & 11.5 & 0.7 & & $\mathrm{X}$ & \\
\hline MF-75/25 & 4 & 11.6 & 0.3 & & $\mathrm{X}$ & \\
\hline MG-50/50 & 4 & 10.9 & 0.7 & & $\mathrm{X}$ & \\
\hline МH-25/75 & 4 & 9.7 & 0.5 & $\mathrm{X}$ & & \\
\hline MI-0/100 & 4 & 9.1 & 0.5 & $\mathrm{X}$ & & \\
\hline \multicolumn{7}{|c|}{90 Days $(p-$ value $=0.0020)$} \\
\hline MA-100/0 & 4 & 12.1 & 0.6 & & & $\mathrm{X}$ \\
\hline MF-75/25 & 4 & 11.8 & 0.9 & & & $\mathrm{X}$ \\
\hline MG-50/50 & 4 & 11.2 & 0.2 & & $\mathrm{X}$ & $\mathrm{X}$ \\
\hline MH-25/75 & 4 & 10.3 & 1.1 & $\mathrm{X}$ & $\mathrm{X}$ & \\
\hline MI-0/100 & 4 & 9.7 & 0.6 & $\mathrm{X}$ & & \\
\hline \multicolumn{7}{|c|}{180 Days $(p-$ value $=0.0128)$} \\
\hline MA-100/0 & 4 & 12.4 & 0.5 & & $\mathrm{X}$ & \\
\hline MF-75/25 & 4 & 12.9 & 0.3 & & $\mathrm{X}$ & \\
\hline MG-50/50 & 4 & 12.8 & 1.2 & & $\mathrm{X}$ & \\
\hline MH-25/75 & 4 & 12.0 & 0.6 & & $\mathrm{X}$ & \\
\hline MI-0/100 & 4 & 10.7 & 1.1 & $\mathrm{X}$ & & \\
\hline
\end{tabular}

compressive strength was less affected by the incorporation of fine RCA because the slope of the linear trend was slightly lower than for the 7-day material (Figure 6). These results can be explained by the higher specific surface of the fine RCA and the amount of non-hydrated cement that completes its hydraulic reaction when in contact with water.

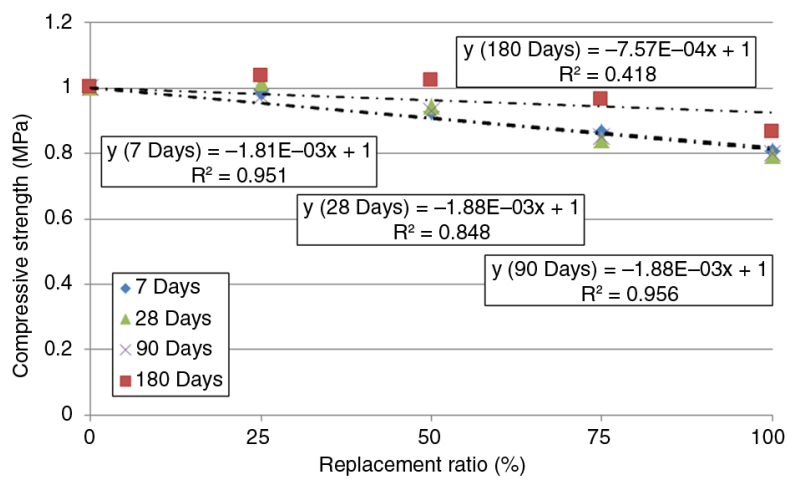

FIGURE 6. Influence of fine RCA replacement ratio on the relative compressive strength at 7 and 180 days. 
Neno et al. (19) found that the incorporation of $100 \%$ fine RCA resulted in a compressive strength improvement of $48.3 \%$ at 28 days of age, whereas in this study the total replacement of NA by fine RCA resulted in a decrease of $20.9 \%$. Ledesma et al. (20) described in detail the reasons for these differences. The most significant reason is that Neno et al. (19) used fine RCA from selected concrete blocks (class 30/37) manufactured in the laboratory and crushed at early ages; therefore, the amount of non-hydrated cement was probably higher than in the recycled aggregates used in this study.

Ledesma et al. (20) demonstrated that replacement ratios of NA by fine RCA up to $40 \%$ did not affect the mechanical properties of M-5 masonry mortar. The best results obtained by Ledesma et al. (20) can be attributable to the cement CEM-IV, which used 29\% fly ash. The combined effect of coal fly ash and RCA improves the properties of concrete (31). These results are explained by the pozzolanic reaction between coal fly ash and $\mathrm{Ca}(\mathrm{OH})_{2}$ of the RCA. Kou and Poon (32) found improvements in the long-term properties of concrete made with fly ash and RCA. These authors proposed that a combination of $50 \%$ of RCA and $25 \%$ replacement ratio of Portland cement by coal fly ash is an optimal solution for recycled concrete production.

Dapena et al. (14) and Vegas et al. (15) concluded that the mechanical strength decreases significantly in mortars when natural sand is replaced by fine RCA. These differences can be explained by the different proportion method employed. This study replaced aggregates by volume, whereas the previous authors replaced NA with RCA by weight. Because of the lower density of the RCA, substituting materials by weight produces a larger volume of lowerquality mortar. Martínez et al. (17) found that the use of fine recycled aggregates, independent of the composition of the CDW origin, improved the compressive strength of the mortar manufactured with the most accessible natural sand in Havana because of the low quality of this natural aggregate.

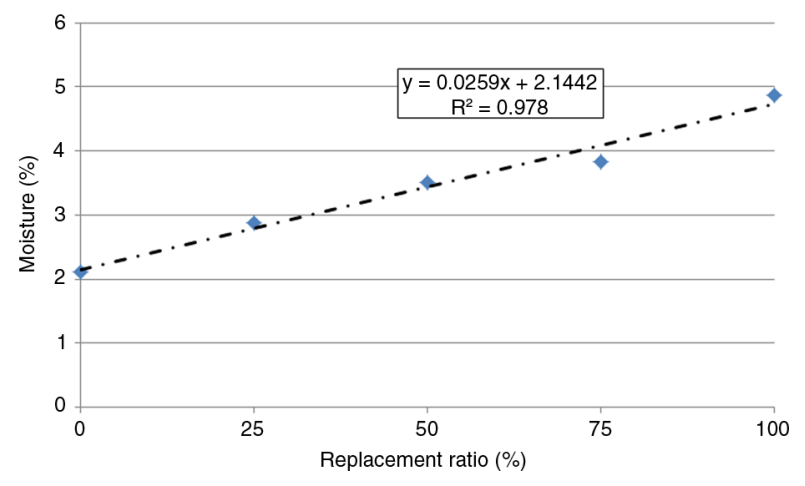

FIGURE 7. Influence of fine RCA replacement ratio on the moisture of the specimen.
The moisture of the specimen was measured after fracture. Although all specimens were cured under the same conditions $\left(\mathrm{HR}=65 \pm 5 \%\right.$ and $\mathrm{T}^{\mathrm{a}}=20 \pm 2{ }^{\circ} \mathrm{C}$ ), mixes with more fine RCA incorporation had a higher moisture content (Figure 7). This can be explained by the higher water absorption capacity of the recycled aggregates, which may limit their use in outdoor environments.

Based on the previous results, a maximum replacement ratio of $50 \%$ can be proposed for M-10 masonry mortar production to ensure a proper performance in terms of compressive strength.

\subsection{Flexural strength of hardened mortar}

Regarding the flexural strength, in all cases $(7,28$, 90 and 180 days) the p-value of the F-test was less than 0.05 (p-value $=0.000$ ); thus, the 'replacement ratio' factor had a significant effect on the flexural strength. The reference mortar displayed greater flexural strength values for all curing times. Between two to four homogeneous groups were identified in the multiple range test (Table 12): four for 7 days and

TABLE 12. Multiple Range Test for flexural strength of hardened mortar by mortar type and curing time. Method: $95 \%$ LSD

\begin{tabular}{|c|c|c|c|c|c|c|}
\hline Mortar & Count & $\begin{array}{l}\text { LS mean } \\
(\mathrm{MPa})\end{array}$ & $\begin{array}{c}\text { SD } \\
\text { (MPa) }\end{array}$ & \multicolumn{3}{|c|}{$\begin{array}{c}\text { Homogeneous } \\
\text { groups }\end{array}$} \\
\hline \multicolumn{7}{|c|}{7 Days $(p-$ value $=0.0000)$} \\
\hline MA-100/0 & 4 & 3.5 & 0.1 & & & $\mathrm{X}$ \\
\hline $\mathrm{MF}-75 / 25$ & 4 & 2.9 & 0.2 & & & $\mathrm{X}$ \\
\hline MG-50/50 & 4 & 2.8 & 0.2 & & $\mathrm{X}$ & $\mathrm{X}$ \\
\hline МH-25/75 & 4 & 2.6 & 0.2 & & $\mathrm{X}$ & \\
\hline MI-0/100 & 4 & 2.2 & 0.3 & $\mathrm{X}$ & & \\
\hline \multicolumn{7}{|c|}{28 Days (p-value $=0.0005$ ) } \\
\hline MA-100/0 & 4 & 3.7 & 0.5 & & & $\mathrm{X}$ \\
\hline $\mathrm{MF}-75 / 25$ & 4 & 3.0 & 0.3 & & & $\mathrm{X}$ \\
\hline MG-50/50 & 4 & 3.0 & 0.3 & & $\mathrm{X}$ & $\mathrm{X}$ \\
\hline MH-25/75 & 4 & 2.6 & 0.2 & $\mathrm{X}$ & $\mathrm{X}$ & \\
\hline MI-0/100 & 4 & 2.5 & 0.3 & $\mathrm{X}$ & & \\
\hline \multicolumn{7}{|c|}{90 Days $(p-v a l u e=0.0063)$} \\
\hline MA-100/0 & 4 & 3.6 & 0.2 & & $\mathrm{X}$ & \\
\hline $\mathrm{MF}-75 / 25$ & 4 & 2.9 & 0.3 & $\mathrm{X}$ & & \\
\hline MG-50/50 & 4 & 2.9 & 0.5 & $\mathrm{X}$ & & \\
\hline MH-25/75 & 4 & 2.9 & 0.2 & $\mathrm{X}$ & & \\
\hline MI-0/100 & 4 & 2.6 & 0.3 & $\mathrm{X}$ & & \\
\hline \multicolumn{7}{|c|}{180 Days $(p-$ value $=0.0083$ ) } \\
\hline MA-100/0 & 4 & 4.9 & 0.5 & & & $\mathrm{X}$ \\
\hline $\mathrm{MF}-75 / 25$ & 4 & 4.3 & 0.1 & & $\mathrm{X}$ & $\mathrm{X}$ \\
\hline MG-50/50 & 4 & 4.1 & 0.4 & $\mathrm{X}$ & $\mathrm{X}$ & \\
\hline MH-25/75 & 4 & 3.9 & 0.5 & $\mathrm{X}$ & $\mathrm{X}$ & \\
\hline MI-0/100 & 4 & 3.5 & 0.6 & $X$ & & \\
\hline
\end{tabular}




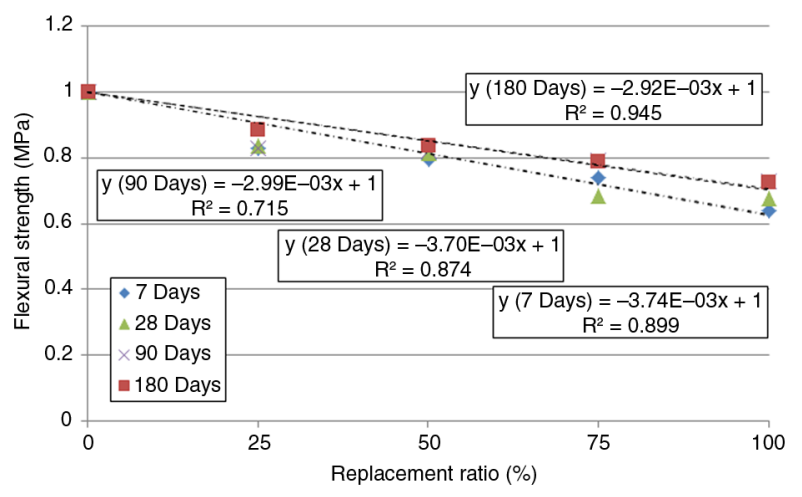

FIGURE 8. Influence of fine RCA replacement ratio on the relative flexural strength at 7 and 180 days.

28 days of curing time, two for 90 days and three for 180 days. All mixes had a similar pattern in the flexural strength. At 7 days, the use of $100 \%$ fine RCA decreased the flexural strength $36 \%$, with respect to the reference mortar, whereas at 180 days the decrease was $28 \%$. From 7 to 180 days the flexural strength increased $42 \%$ in the reference mortar, whereas in mortar with $100 \%$ fine RCA the increase was $60 \%$.

Flexural strength decreased linearly with a rising replacement ratio (Figure 8). As observed for compressive strength, flexural strength was more affected by the incorporation of fine RCA at early ages. Comparing the slopes of the trend lines in Figure 6 and Figure 8, we noted that the compressive strength was more affected than the flexural strength with the use of fine RCA.

These results are in agreement with what happens in concrete made with coarse RCA, where flexural strength exhibits lower reduction than compressive strength (33). Neno et al. (19) showed a similar pattern in flexure and compression.

\subsection{Dimensional instability (drying shrinkage)}

Linear shrinkage $(\mathrm{mm} / \mathrm{m})$ was higher in the mortars manufactured with fine RCA than the reference mortar (Figure 9). A one-way ANOVA test was

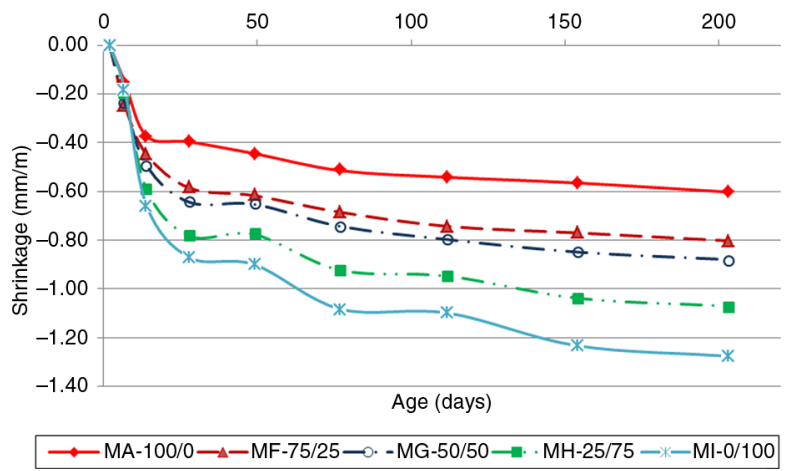

FiguRE 9. Dimensional instability (shrinkage) over time.
TABLE 13. Multiple Range Test for shrinkage of hardened mortar by mortar type and curing time. Method: $95 \%$ LSD

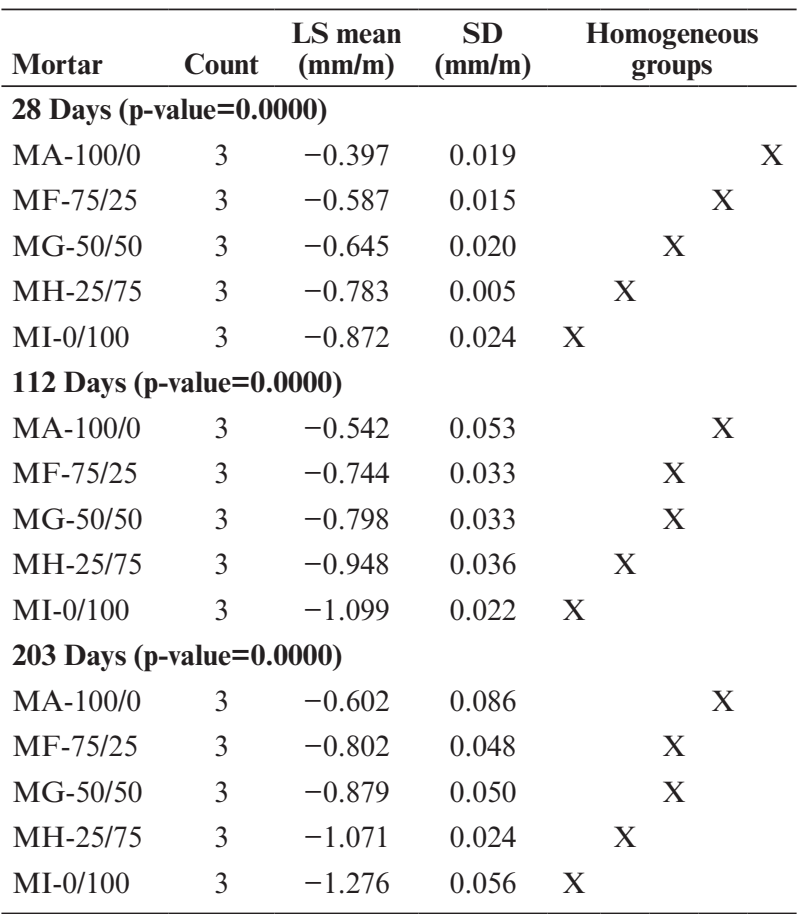

conducted at 28, 112 and 203 days of curing. In all cases, the p-value of the F-test was less than 0.05 ( $\mathrm{p}$-value $=0.000)$; thus, the 'replacement ratio' factor had a significant effect on the dimensional instability. Table 13 shows the homogeneous groups identified in the multiple-range test. Figure 10 shows the percentage of weight loss of the mortar specimens during the shrinkage test. The weight loss is attributable to water loss. Mortars made with fine RCA had greater weight loss because these mortars needed more water for mixing. After 60 days, slight increases in weight were measured, which may be due to carbonation reactions (34).

These results are consistent with the literature. Vegas et al. (15), Braga et al. (18) and Neno et al. (19) indicated that shrinkage increased with the

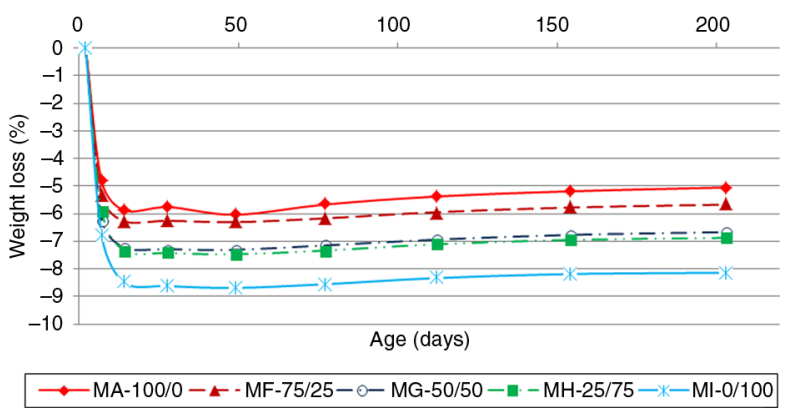

Figure 10. Weight loss of the mortar specimens during the shrinkage test. 
incorporation of fine RCA. The high total water/ cement ratio in the mixture is the first cause of the increase in the shrinkage of recycled mortars (17). In contrast, Ledesma et al. (20) concluded that replacement ratios up to $40 \%$ did not affect the shrinkage mean values after one year of measurements. This can be attributed to the type of cement and dosage method.

Based on the shrinkage values, Ledesma et al. (35) proposed two criteria to set the maximum incorporation ratio: the shrinkage value must not exceed $1 \mathrm{~mm} / \mathrm{m}$ and the difference with respect to the reference mortar must not exceed $0.5 \mathrm{~mm} / \mathrm{m}$. A replacement rate of $50 \%$ meets both criteria; thus, a maximum replacement ratio of $50 \%$ could be suggested for masonry mortar production to ensure proper performance in terms of drying shrinkage.

Tests to measure the susceptibility to cracking and evaluations in real conditions of the development of cracks are necessary.

\subsection{Adhesive strength}

The p-value of the F-test was less than 0.05 ( $p$-value $=0.000)$; thus, the 'replacement ratio' factor had a significant effect on this property. The multiple-range test showed two homogeneous groups (Table 14): the reference mortar and the recycled mortars. The reference mortar displayed an unreasonably high value compared to the recycled mortars. This can be attributed to the greater amount of free water derived from the higher effective water/cement ratio. However, this would not explain all the results of the recycled mortars; therefore, the high adhesive strength value of the reference mortar may be considered spurious data.

Corinaldesi et al. (36) and Corinaldesi and Moriconi (12) found that RA mortars displayed higher mortar-brick bond strengths than the reference mortar. Braga et al. (18) also achieved significant improvement in the mortar's adherence capacity with the incorporation of $15 \%$ concrete fines. Ledesma et al. (20) found that mortars made with $10 \%$ and $20 \%$ RCA fines exhibited the highest adhesive strength values, although all of the mortars

TABLE 14. Multiple Range Test for adhesive strength of hardened mortar by mortar type and curing time. Method: 95\% LSD

\begin{tabular}{lcccc}
\hline Mortar & Count & $\begin{array}{c}\text { LS mean } \\
(\mathbf{M P a})\end{array}$ & $\begin{array}{c}\text { SD } \\
(\mathbf{M P a})\end{array}$ & $\begin{array}{c}\text { Homogeneous } \\
\text { groups }\end{array}$ \\
\hline MA-100/0 & 4 & 0.47 & 0.11 & \multicolumn{2}{|}{ X } \\
MF-75/25 & 4 & 0.26 & 0.15 & $\mathrm{X}$ \\
MG-50/50 & 4 & 0.25 & 0.03 & $\mathrm{X}$ \\
MH-25/75 & 4 & 0.25 & 0.05 & $\mathrm{X}$ \\
MI-0/100 & 4 & 0.29 & 0.04 & $\mathrm{X}$ \\
\hline
\end{tabular}

tested exhibited values between 0.38 and $0.58 \mathrm{MPa}$. Other authors did not include this parameter in their studies $(14,15,21)$.

\subsection{Capillary absorption}

The p-value of the F-test was less than 0.05 ( $p$-value $=0.000$ ); thus, the 'replacement ratio' factor had a significant effect on this property. The multiplerange test showed that no statistically significant differences were observed for replacement ratios below $75 \%$ (Table 15), although the mean values increased slightly with the use of fine RCA because of the higher water absorption of recycled concrete sand.

These results are in agreement with those obtained by Martínez et al. (17) and Silva et al. (37), who demonstrated that mortars manufactured with recycled aggregates had a higher capillary absorption capacity than reference mortars. Neno et al. (19) found similar capillarity absorption for replacement ratios below 50\%. Ledesma et al. (20) achieved the lowest values with replacement ratios of $5 \%$ and $10 \%$. Other authors did not include this parameter in their studies $(14,15,21)$.

A maximum replacement ratio of $75 \%$ could be suggested for masonry mortar production to ensure proper performance in terms of capillary absorption.

\subsection{Durability}

Mortars MG-50/50 and MI-0/100, manufactured with $50 \%$ and $100 \%$ replacement ratios, respectively, displayed a higher percent of weight loss after 15 cycles in sodium sulfate dissolution than the reference mortar, according to UNE-EN 12370:1999 (Table 16). These results agree with those obtained by Vegas et al. (15) who demonstrated a weight loss

TABLE 15. ANOVA table for water absorption due to capillary of hardened mortar by mortar type

\begin{tabular}{|c|c|c|c|c|}
\hline Mortar & Count & $\begin{array}{c}\text { LS mean } \\
\left(\mathrm{kg} /\left(\mathrm{m}^{2} \min ^{-0.5}\right)\right)\end{array}$ & SD & $\begin{array}{c}\text { Homogeneous } \\
\text { groups }\end{array}$ \\
\hline MA-100/0 & 6 & 0.59 & 0.02 & $\mathrm{X}$ \\
\hline MF-75/25 & 6 & 0.59 & 0.02 & $\mathrm{X}$ \\
\hline MG-50/50 & 6 & 0.62 & 0.02 & $\mathrm{X}$ \\
\hline MH-25/75 & 6 & 0.62 & 0.05 & $\mathrm{X}$ \\
\hline MI-0/100 & 6 & 0.67 & 0.06 & $X$ \\
\hline
\end{tabular}

TABLE 16. Percent of weight loss after 15 cycles in sodium sulphate dissolution

\begin{tabular}{lccc}
\hline Mortar & Count & LS mean (\%) & SD (\%) \\
\hline MA-100/0 & 4 & 2.20 & 0.40 \\
MG-50/50 & 4 & 3.82 & 0.41 \\
MI-0/100 & 4 & 8.73 & 2.07 \\
\hline
\end{tabular}


of $2.6 \%$ and $5.5 \%$ in the reference mortar and mortar with a $25 \%$ replacement ratio, respectively. Accordingly, mortars prepared with fine RCA appear to be less resistant to salt crystallization. Having a more permeable mortar, which is highlighted by increased water absorption by capillarity, sulfates can more easily penetrate into the mortar structure. These sulfates react with portlandite forming secondary gypsum in the presence of the tricalcium aluminate $(\mathrm{C} 3 \mathrm{~A})$, giving rise to the formation of expansive ettringite $(38,39)$. Dimensional changes at the surface of the concrete generate cracks, which act as capillaries for the transport of water and sulfates deeper into the mortar. This process continues as the mortars disintegrate (40). This negative property can limit the use of mortar with recycled aggregate in outdoor environments that are at risk of frost, but this property does not limit their use in indoor environments. Figure 11 shows the appearance of prism specimens after 15 cycles in sodium sulfate dissolution.
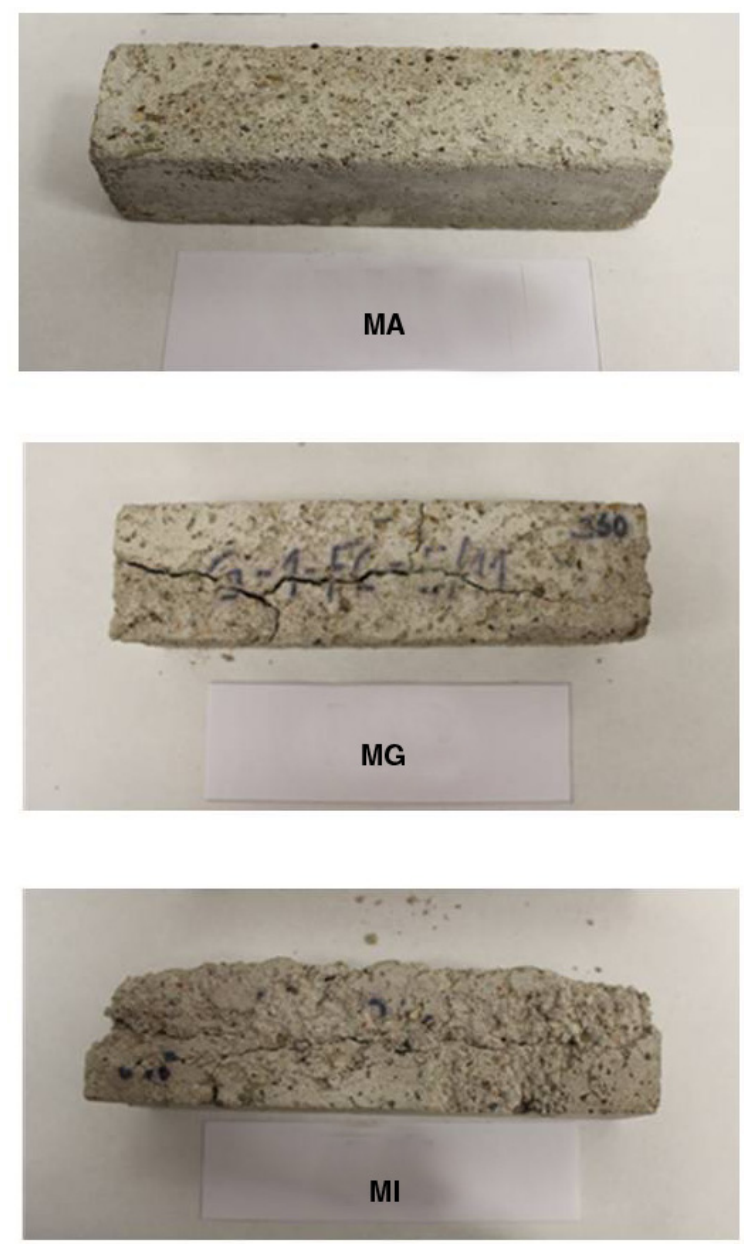

FIGURE 11. Appearance of prism specimens after 15 cycles in sodium sulphate dissolution.

\section{CONCLUSIONS}

This study proposes a maximum feasible use of recycled concrete sand in the manufacturing of type M-10 masonry mortars. Five mortars were tested with different replacement ratios of $0 \%, 25 \%, 50 \%$, $75 \%$ and $100 \%$ by volume. The most innovative aspects of this work were the following: a) maintaining the original grading curves of the recycled concrete sand; b) using a volumetric dosage method; c) determining a dosage to obtain a mortar type M-10 using a commercial cement and a commercial admixture in the manufacture of mortars, thereby ensuring a knowledge transfer to industry; and d) not pre-saturating the recycled aggregates. The primary conclusions can be drawn as follows:

The bulk density of fresh mortar was not affected with replacement ratios below $50 \%$, whereas higher replacement ratios caused significant decreases. The use of fine RCA did not have a significant effect on the entrained air, whereas the mean workability values decreased with replacement ratios above $25 \%$.

The dry bulk density of hardened mortar decreased with replacement ratios above $25 \%$. The compressive and flexural strength displayed similar behaviors over time. Replacement ratios of up to $50 \%$ did not significantly affect the mean compressive strength values for any of the curing times, whereas replacement ratios of $100 \%$ produced significant decreases. Compressive strength displayed a higher reduction compared with flexural strength. For the same environmental conditions, mortars with fine RCA had higher moisture content than the reference mortar.

The shrinkage of hardened mortar displayed a similar trend over time. Mortars made with fine RCA displayed higher shrinkage than the reference mortar. No traces of ettringite were detected. Bonding strength decreased with replacement ratios above $25 \%$. Replacement ratios of up to $75 \%$ did not affect the mean values of capillary absorption. Mortars prepared with fine RCA were less resistant to salt crystallization, which may limit their use in outdoor environments that are at risk of frost.

In view of the results of this work and considering the requirements of masonry mortars, the maximum recommended replacement ratio of natural sand by recycled sand from concrete waste in indoor environmental conditions without reducing the properties of the reference mortar can be fixed at $50 \%$ by volume. Findings from this study encourage the conservation of non-renewable natural resources and an increase in the recycling rate of the fine fraction of CDW. To encourage an increase in this rate, new studies using different types of cement and admixtures are being conducted by this research group.

\section{ACKNOWLEDGMENT}

This research was partially funded by the University of Cordoba's Andalusian Research Group TEP-227. 


\section{REFERENCES}

1. Kamrath, P. (2013) Demolition techniques and production of construction and demolition waste (CDW) for recycling. In: Pacheco-Torgal, F., Tam, V.W.Y., Labrincha, J.A., Ding, Y. de Brito, J. (Eds.), Handbook of recycled concrete and demolition waste. Woodhead Publishing Limited, Cambridge, U.K., 186-208.

2. Coelho, A.; de Brito, J. (2013) Conventional demolition versus deconstruction techniques in managing construction and demolition waste (CDW). In: Pacheco-Torgal, F. Tam, V.W.Y., Labrincha, J.A., Ding, Y. de Brito, J. (Eds.), Handbook of recycled concrete and demolition waste. Woodhead Publishing Limited, Cambridge, U.K., 141-183.

3. Jiménez, J.R.; Agrela, F.; Ayuso, J.; López, M. (2011) A comparative study of recycled aggregates from concrete and mixed debris as materials for unbound road sub-base. Mater. Construcc. 61 [302], 289-302. http://dx.doi.org/10.3989/mc. 2010.54009 .

4. Jiménez, J.R. (2013) Recycled aggregates (RAs) for roads. In: Pacheco-Torgal, F., Tam, V.W.Y., Labrincha, J.A., Ding, Y. de Brito, J. (Eds.), Handbook of recycled concrete and demolition waste. Woodhead Publishing Limited, Cambridge, U.K., 351-376. http://dx.doi.org/10.1533/9780857096906.3.351.

5. Etxeberria, M.; Vázquez, E.; Marí, A.; Barra. M. (2007) Influence of amount of recycled coarse aggregates and production process on properties of recycled aggregate concrete. Cem. Concr. Res. 37, 735-742. http://dx.doi.org/10.1016/j. cemconres.2007.02.002

6. Evangelista, L.; de Brito, J. (2007) Mechanical behaviour of concrete made with fine recycled concrete aggregates. Cem. Concr. Comp. 29, 397-401. http://dx.doi.org/10.1016/j. cemconcomp.2006.12.004.

7. Kou, S.C.; Poon, C.S. (2009) Properties of concrete prepared with crushed fine stone, furnace bottom ash and fine recycled aggregate as fine aggregates. Constr. Build. Mater. 23, 2877-2886. http://dx.doi.org/10.1016/j.conbuildmat. 2009.02.009.

8. Pereira, P.; Evangelista, L.; de Brito, J. (2012) The effect of superplasticizers on the mechanical performance of concrete made with fine recycled concrete aggregates. Cem. Concr. Comp. 34, 1044-1052. http://dx.doi.org/10.1016/j. cemconcomp.2012.06.009.

9. Evangelista, L.; de Brito, J. (2010) Durability performance of concrete made with fine recycled concrete aggregates. Cem. Concr. Compos. 32, 9-14. http://dx.doi.org/10.1016/j. cemconcomp.2009.09.005.

10. Gonçalves, P.; de Brito, J. (2010) Recycled aggregate concrete (RAC) - comparative analysis of existing specifications. Mag. Con. Res. 62 [5], 339-346. http://dx.doi.org/10.1680/ macr.2008.62.5.339

11. Evangelista, L.; de Brito, J. (2014) Concrete with fine recycled aggregates: a review. Europ. J. Envi. Civ. Eng. 18 [2], 129-172. http://dx.doi.org/10.1080/19648189.2013.851038.

12. Corinaldesi, V.; Moriconi, G. (2009) Behaviour of cementitious mortars containing different kinds of recycled aggregate. Constr: Build. Mater. 23, 289-294. http://dx.doi.org/10.1016/j. conbuildmat.2007.12.006

13. Corinaldesi, V. (2009) Mechanical behaviour of masonry assemblages manufactured with recycled-aggregate mortars. Cem. Concr. Compos. 31, 505-510. http://dx.doi.org/10.1016/j. cemconcomp.2009.05.003.

14. Dapena, E.; Alaejos, P.; Lobet, A.; Pérez, D. (2011) Effect of recycled sand content on characteristics of mortars and concretes. J. Mater. Civ. Eng. 23 [4], 414-422. http://dx.doi. org/10.1061/(ASCE)MT.1943-5533.0000183.

15. Vegas, I.; Azkarate, I.; Juarrero, A.; Frías, M. (2009) Design and performance of masonry mortars made with recycled concrete aggregates. Mater. Construcc. 59 [295], 5-18. http:// dx.doi.org/10.3989/mc.2009.44207.

16. Jiménez, J.R.; Ayuso, J.; López, M.; Fernández, J.M.; de Brito, J. (2013) Use of fine recycled aggregates from ceramic waste in masonry mortar manufacturing. Constr. Build. Mater. 40, 679-690. http://dx.doi.org/10.1016/j.conbuildmat. 2012.11.036.
17. Martínez, I.; Etxeberria, M.; Pavón, E.; Díaz, N. (2013) A comparative analysis of the properties of recycled and natural aggregate in masonry mortars. Constr. Build. Mater. 49, 384-392. http://dx.doi.org/10.1016/j.conbuildmat.2013. 08.049 .

18. Braga, M.; de Brito, J.; Veiga, R. (2012) Incorporation of fine concrete aggregates in mortars. Constr. Build. Mater. 36, 960-968. http://dx.doi.org/10.1016/j.conbuildmat.2012. 06.031 .

19. Neno, C.; de Brito, J.; Veiga, R. (2014) Using fine recycled concrete aggregate for mortar production. Mater. Res. 17 [1], 168-177. http://dx.doi.org/10.1590/S151614392013005000164.

20. Ledesma, E.F.; Jiménez, J.R.; Fernández, J.M.; Galvín, A.P.; Agrela, F.; Barbudo, A. (2014) Properties of masonry mortars manufactured with fine recycled concrete aggregates. Constr. Build. Mater. 71, 289-98. http://dx.doi.org/10.1016/j. conbuildmat.2014.08.080.

21. Cuenca-Moyano, G.M.; Martín-Morales, M.; ValverdePalacios, I.; Valverde-Espinosa, I.; Zamorano, M. (2014) Influence of pre-soaked recycled fine aggregate on the properties of masonry mortar. Constr. Build. Mater. 70, 71-79. http://dx.doi.org/10.1016/j.conbuildmat.2014.07.098

22. Ulsen, C.; Kahn, H.; Hawlitschek, G.; Masini, E.A.; Angulo, S.C.; John, V.M. (2013) Production of recycled sand from construction and demolition waste. Constr. Build. Mater. 40, 1168-1173. http://dx.doi.org/10.1016/j. conbuildmat.2012.02.004.

23. Rodrigues, F.; Carvalho, M.T.; Evangelista, L.; de Brito, J. (2013) Physical-chemical and mineralogical characterization of fine aggregates from construction and demolition waste recycling plants. J. Clean. Prod. 52, 438-445. http:// dx.doi.org/10.1016/j.jclepro.2013.02.023.

24. Cartuxo, F.; de Brito, J.; Evangelista, L.; Jiménez, J.R.; Ledesma, E.F. (2015) Rheological behaviour of concrete made with fine recycled concrete aggregates - Influence of the superplasticizers. Constr. Build. Mater. 89, 26-47. http:// dx.doi.org/10.1016/j.conbuildmat.2015.03.119.

25. Ferreira, L.; de Brito, J.; Barra, M. (2011) Influence of the pre-saturation of recycled coarse concrete aggregates on concrete properties. Mag. Conc. Res. 63 [8], 617-627. http:// dx.doi.org/10.1680/macr.2011.63.8.617.

26. Pereira, P.; Evangelista, L.; de Brito, J. (2012) The effect of superplasticisers on the workability and compressive strength of concrete made with fine recycled concrete aggregates. Constr. Build. Mater. 28, 722-729. http://dx.doi.org/10.1016/j. conbuildmat.2011.10.050.

27. Jiménez, J.R.; Ayuso, J.; Agrela, F.; López, M.; Galvín, A.P. (2012) Utilisation of unbound recycled aggregates from selected CDW in unpaved rural roads. Resour. Conserv. Recy. 58, 88-97. http://dx.doi.org/10.1016/j.resconrec.2011.10.012.

28. Jiménez, J.R.; Ayuso, J.; Galvín, A.P.; López, M.; Agrela, F. (2012) Use of mixed recycled aggregates with a low embodied energy from non-selected CDW in unpaved rural roads. Constr. Build. Mater. 34, 34 43. http://dx.doi.org/10.1016/j. conbuildmat.2012.02.042.

29. Mefteh, H.; Kebaïli, O.; Oucief, H.; Berredjem, L.; Arabi, N. (2013) Influence of moisture conditioning of recycled aggregates on the properties of fresh and hardened concrete. J. Clean. Prod. 54, 282-288. http://dx.doi.org/10.1016/j. jclepro.2013.05.009

30. Poon, C.S.; Shui, Z.H.; Lam, L.; Fok, H.; Kou, S.C. (2004) Influence of moisture states of natural and recycled aggregates on the slump and compressive strength of concrete. Cem. Concr. Res. 34 [1], 31-36. http://dx.doi.org/10.1016/ S0008-8846(03)00186-8.

31. Kim, K.; Shin, M.; Cha, S. (2013) Combined effects of recycled aggregate and fly ash towards concrete sustainability. Constr. Build. Mater. 48, 499-507. http://dx.doi.org/10.1016/j. conbuildmat.2013.07.014.

32. Kou, S.C.; Poon, C.S. (2013) Long-term mechanical and durability properties of recycled aggregate concrete prepared with the incorporation of fly ash. Cem. Concr. Compos. 37, 12-19. http://dx.doi.org/10.1016/j.cemconcomp.2012. 12.011. 
33. Katz, A. (2003) Properties of concrete made with recycled aggregate from partially hydrated old concrete. Cem. Concr. Res. 33, 703-711. http://dx.doi.org/10.1016/S0008-8846 (02)01033-5.

34. Quattrone, M.; Angulo, S.C.; John, V.M. (2014) Energy and $\mathrm{CO}_{2}$ from high performance recycled aggregate production. Resour. Conserv. Recy. 90, 21-33. http://dx.doi.org/ 10.1016/j.resconrec.2014.06.003.

35. Ledesma, E.F; Jiménez, J.R: Ayuso, J; Fernández, JM: de Brito, J. (2015) Maximum feasible use of recycled sand from construction and demolition waste for eco-mortar production - Part-I: ceramic masonry waste. J. Clean Prod. 87, 692-706. http://dx.doi.org/10.1016/j.jclepro.2014.10.084.

36. Corinaldesi, V.; Giuggiolini, M.; Moriconi, G. (2002) Use of rubble from building demolition in mortars. Waste Manage. 22, 893-899. http://dx.doi.org/10.1016/S0956-053X (02)00087-9.
37. Silva, J.; de Brito, J.; Veiga, R. (2010) Recycled red-clay ceramic construction and demolition waste for mortars production. J. Mater. Civ. Eng. 22 [3], 236-244. http://dx.doi. org/10.1061/(ASCE)0899-1561(2010)22:3(236).

38. Aye, T.; Oguchi, C.T. (2001) Resistance of plain and blended cement mortar exposed to severe sulphate attacks. Constr. Build. Mater. 25, 2988-2996. http://dx.doi.org/10.1016/j. conbuildmat.2010.11.106.

39. Sahmaran, M.; Kasap, O.; Duru, K.; Yaman, I.O. (2007) Effects of mix composition and water-cement ratio on the sulfate resistance of blended cements. Cem. Concr. Compos. 29, 159-67. http://dx.doi.org/10.1016/j.cemconcomp.2006. 11.007.

40. Chen, J.; Jiang, M. (2009) Long-term evolution of delayed ettringite and gypsum in Portland cement mortars under sulphate erosion. Constr. Build. Mater. 23, 812-816. http:// dx.doi.org/10.1016/j.conbuildmat.2008.03.002. 